\title{
Identifikasi Kenyamanan Kota Tanjungpinang Berdasarkan Indeks Panas Humidex
}

\author{
Diana Cahaya Siregar¹, Vivi Putrima Ardah¹, Regina Dara Ninggar²
}

${ }^{1}$ Stasiun Meteorologi Tanjungpinang - Jl. Adi Sucipto Km. 12.5, Bandara Raja Haji Fisabilillah, Tanjungpinang, 29125; e-mail: siregardianacahaya@gmail.com

${ }^{2}$ Balai Besar Meteorologi Klimatologi dan Geofisika Wilayah II - Jl. Abdul Ghani No. 5 Cempaka Putih, Ciputat Timur, Tangerang Selatan, Banten, 15412

\begin{abstract}
ABSTRAK
Perkembangan Kota Tanjungpinang di beberapa sektor merupakan upaya untuk menjadikan Kota Tanjungpinang yang lebih maju. Namun, di sisi lain terdapat masalah penting yang perlu diperhatikan yaitu masalah indeks kenyamanan hidup penduduk yang tinggal di Kota Tanjungpinang. Fenomena iklim dapat mempengaruhi kenyamanan fisiologis di suatu daerah. Peningkatan suhu secara periodik dapat memicu terjadinya fenomena Urban Heat Island. Penelitian ini akan mengkaji tingkat kenyamanan di Kota Tanjungpinang dengan menggunakan indeks panas yaitu Humidex dengan menggunakan data klimatologi berupa suhu udara, kelembaban udara, dan kecepatan angin permukaan untuk periode 1989-2018 dari Stasiun Meteorologi Tanjungpinang. Perbandingan Humidex terhadap kecepatan angin dan jumlah kendaraan bermotor di Kota Tanjungpinang dilakukan untuk mengetahui pengaruhnya terhadap indeks panas di Kota Tanjungpinang. Hasil penelitian menunjukkan rata-rata Humidex bulanan di wilayah Kota Tanjungpinang berkisar antara 32.6-34.0 ${ }^{\circ} \mathrm{C}$. Nilai tertinggi Humidex rata-rata bulanan terjadi pada bulan Mei dan Juni, sedangkan nilai terendah terjadi pada bulan Januari. Terjadi kecenderungan peningkatan Humidex berkisar 0.08-0.9 ${ }^{\circ} \mathrm{C}$ dan penurunan Humidex berkisar 0.07-0.8 ${ }^{\circ} \mathrm{C}$ dengan nilai koefisien determinasi berkisar 0.55. Peningkatan kecepatan angin akan menyebabkan penurunan nilai Humidex. Bertambahnya jumlah kendaraan bermotor secara periodik berpengaruh terhadap peningkatan nilai Humidex secara eksponensial. Peningkatan emisi Gas Rumah Kaca berdampak terhadap tingkat kenyaman termis yang dirasakan populasi yang tinggal di Kota Tanjungpinang menjadi kurang nyaman akibat polusi udara yang dihasilkan oleh kendaraan bermotor. Terdapat peningkatan rasa nyaman termis ketika terjadi penurunan nilai Humidex atau sebaliknya. Tren peningkatan nilai indeks panas di wilayah Kota Tanjungpinang disebabkan akibat semakin meningkatnya perubahan penggunaan lahan menjadi lahan terbangun, galaknya program urbanisasi, dan maraknya penggunaan kendaraan bermotor.
\end{abstract}

Kata kunci: Humidex, Kenyamanan Termis, Urban Heat Island, Indeks Panas, Kota Tanjungpinang

\begin{abstract}
The development of Tanjungpinang City in several sectors is an effort to make that city more advance. However, there is an important problem that needs to be considered. It is the problem of the comfort life index for the population who are living in Tanjungpinang City. The climate change can affect physiological comfort in an area. The increasing of temperature can trigger the Urban Heat Island. The aim of this study is to know the comfort life index in Tanjungpinang City using a heat index called as Humidex. The data are the air temperature, air humidity, and surface wind speed for the period of 1989-2018 from the Tanjungpinang Meteorological Station. The comparison of Humidex to wind speed and the number of vehicles in Tanjungpinang City was calculated to determine the effect on the heat index in Tanjungpinang City. The results show that the Humidex monthly average in the Tanjungpinang City area ranged from 32.6 to $34.0^{\circ} \mathrm{C}$. The highest Humidex monthly average is in May and June, and the lowest value is in January. The tendency of increasing Humidex ranged from 0.08 to $0.9{ }^{\circ} \mathrm{C}$ and decreasing ranged from 0.07 to 0.8 ${ }^{\circ} \mathrm{C}$ with the determinant coefficient value is 0.55 . The increasing of wind speed impacts to decrease the value of Humidex. The increasing of the number of vehicles periodically impacts to increase the value of Humidex exponentially. The increasing of Greenhouse Gas emissions has an impact on the thermal comfort felt by the population who are living in Tanjungpinang City which it is less comfortable due to the air pollutions are generated by vehicles. There is an increasing of the thermal comfort when there is a decreasing value of Humidex or vice versa. The increasing of heat index in the Tanjungpinang City region is due to the increasing of land use changed to built up land, the urbanization program, and the using of vehicles.
\end{abstract}

Keywords: Humidex, Thermal Comfort, Urban Heat Island, Heat Index, Tanjungpinang City

Citation: Siregar, D. C., Ardah, V. P., dan Ninggar, R. D. (2019). Identifikasi Kenyamanan Kota Tanjungpinang Berdasarkan Indeks Panas Humidex. Jurnal Ilmu Lingkungan, 17(2), 316-322, doi:10.14710/jil.17.2.316-322 


\section{Pendahuluan}

Tanjungpinang adalah ibu kota dari Provinsi Kepulauan Riau. Kota ini terletak di Pulau Bintan dengan koordinat $0^{\circ} 5^{\prime}$ LU dan 104027' BT. Perancangan Kota Tanjungpinang masih kurang memperhatikan aspek iklim. Problematik yang ditimbulkan oleh iklim tropis basah berupa: jumlah curah hujan yang tinggi, suhu udara yang umumnya berada diatas toleransi kenyamanan, radiasi matahari yang cukup menyengat, kelembaban udara yang cukup basah serta aliran udara yang relatif lambat bagi pencapaian kenyamanan termis (Kusumastuty, dkk., 2017). Aspek-aspek tersebut tidak dapat diantisipasi dengan baik oleh perencana maupun perancang kota (Sobirin dan Fatimah, 2015). Urbanisasi memiliki dampak positif dan negatif bagi suatu kota. Dengan adanya urbanisasi, keterbutuhan akan sumber daya manusia di kota dapat terpenuhi. Bertambahnya jumlah penduduk di Tanjungpinang berdampak terhadap peningkatan: rumah tinggal (perumahan), jumlah polusi kendaraan dan sumber panas buatan dari kegiatan industri. Hal tersebut dapat menimbulkan masalah lingkungan khususnya mempengaruhi iklim Kota Tanjungpinang.

Perkembangan antropogenik (kegiatan manusia) telah meningkatkan jumlah emisi $\mathrm{CO}_{2}$ khususnya dalam hal penggunaan bahan bakar secara langsung maupun tidak langsung. Menurut Karyono (2001), banyak penghuni kota harus menggunakan kendaraan hanya untuk menuju kantor pos, menuju bank, bahkan untuk sekedar potong rambut sekalipun. Meningkatnya suhu dan pencemaran udara berdampak langsung terhadap perubahan ekosistem kota. Kehadiran zat-zat pencemar di udara yang tekonsentrasi di suatu tempat merupakan hasil dari faktor: sumber emisi, karakteristik zat, kondisi meteorologi, klimatologi, topografi dan geografi (Sangkertadi, 2006). Menurut para ahli, emisi $\mathrm{CO}_{2}$ yang berlebihan dapat menyebabkan kerusakan lingkungan. Kejadian yang telah terasa saat ini yaitu bergesernya siklus musim dan meningkatnya suhu panas bumi.

Perubahan unsur iklim dapat terjadi pada: suhu udara, penerimaan radiasi matahari, kecepatan angin, dan perawanan (Kalfuadi, 2009). Dari unsurunsur tersebut, yang dapat dirasakan secara langsung perubahannya adalah suhu udara. Suhu udara di kota lebih panas dibandingkan dengan di desa dimana fenomena tersebut disebut Urban Heat Island (UHI). Perubahan suhu udara terus meningkat dan berpengaruh terhadap kenyamanan manusia. Kenyamanan termis sangat dibutuhkan tubuh agar manusia dapat beraktifitas dengan baik (Talarosha, 2005). Dalam kenyamanan termis, manusia merasakan sensasi panas atau dingin sebagai wujud respon dari sensor perasa yang terdapat pada permukaan kulit terhadap perubahan suhu udara (Karyono, 2001). Ilmu kenyamanan termis hanya membatasi pada kondisi udara tidak ekstrem (moderate thermal environment) dimana manusia masih dapat mengantisipasi dirinya terhadap perubahan suhu udara di sekitarnya. Berdasarkan
International Standard (ISO 7730:1994), standar kenyamanan thermis manusia terhadap suhu merupakan fungsi dari empat faktor iklim (suhu udara, radiasi matahari, kelembaban udara, dan kecepatan angin) serta dua faktor individu (tingkat kegiatan yang berkaitan dengan tingkat metabolisme tubuh dan jenis pakaian yang dikenakan).

Secara klimatologis pada bulan NovemberJanuari, wilayah Tanjungpinang akan mengalami kondisi basah (curah hujan yang terjadi cukup banyak) dan kondisi kering (curah hujan yang terjadi sedikit) pada bulan Februari (Siregar, dkk., 2019). Hubungan kompleks antara faktor cuaca dengan kesehatan dan kenyamanan manusia dapat diidentifikasikan dengan menggunakan indeks biometeorologi. Menurut Spridonov, dkk. (2013), ada beberapa indeks panas yang berkaitan dengan manusia dan lingkungan yaitu: Heat Discomfort Index, Humidex, The Weather Stress Index, dan The Universal Thermal Climate Index. Pengkajian kenyamanan Kota Tanjungpinang menggunakan indeks panas yaitu Humidex. Rana, dkk. (2013) menyatakan Humidex merupakan prediktor yang baik untuk pemodelan kenyamanan suhu ruangan indoor (dalam ruangan) pada situasi iklim dengan kelembapan tinggi. Wati dan Nasution (2018) dalam penelitiannya menyatakan terdapat peningkatan sensasi panas di wilayah DKI Jakarta sehingga berdampak terhadap penurunan tingkat kenyamanan thermis. Humidex akan menghitung nilai suhu dan kelembaban udara menjadi suatu nilai indeks yang merefleksikan tingkat kenyamanan thermis yang dirasakan oleh manusia. Tujuan dari penelitian ini yaitu untuk mengetahui tingkat kenyamanan thermis Kota Tanjungpinang dengan menggunakan Humidex. Dalam penelitian ini, analisis perbandingan Humidex terhadap kecepatan angin dan jumlah kendaraan bermotor di Kota Tanjungpinang juga dilakukan untuk mengetahui pengaruhnya terhadap indeks panas di Kota Tanjungpinang.

\section{Data dan Metode}

Data yang digunakan dalam penelitian ini yaitu data klimatologi iklim periode 1989-2018 dari Stasiun Meteorologi Tanjungpinang. Parameter iklim yang digunakan adalah suhu (T), kelembaban relatif udara permukaan (RH), dan kecepatan angin permukaan. Metode yang digunakan dalam penelitian ini adalah mencari indeks kenyamanan berdasarkan Humidex yang pertama kali ditemukan oleh Lally dan Watson pada tahun 1960 dan dimodifikasi oleh Masterson dan Richardson pada tahun 1979. Data jumlah kendaraan bermotor di Kota Tanjungpinang untuk periode 2014-2017 diperoleh dari Badan Pusat Statistik (BPS) Kota Tanjungpinang.

Humidex didefinisikan sebagai suhu pada udara yang relatif kering (tekanan uap kurang dari $10 \mathrm{hPa}$ ) yang memiliki pengaruh kenyamanan pada manusia yang sama dengan udara dengan suhu dan kelembaban udara yang diukur secara aktual 
maupun yang dimodelkan (hasil prediksi). Ketidaknyamanan yang dirasakan oleh manusia dalam cuaca panas sangat tergantung pada kelembaban udara dan suhu udara yang sebenarnya. Masterson dan Richardson (1979) menghubungkan ketidaknyamanan termis di luar ruangan (outdoor) di Kanada dengan menggunakan dua parameter utama meteorologi yaitu suhu udara dan kelembapan relatif. Adapun rumusan Humidex yaitu :

$$
\begin{aligned}
& \text { Humidex }=\mathrm{T}+\frac{5}{9}(\mathrm{e}-10) \\
& \mathrm{e}=6.112 \times 10^{\frac{7.5 \mathrm{~T}}{237.7+\mathrm{T}}} \times \frac{\mathrm{AH}}{100}
\end{aligned}
$$

Keterangan :

$$
\begin{array}{ll}
\text { Humidex } & =\text { indeks panas }\left({ }^{\circ} \mathrm{C}\right) \\
\mathrm{T} & =\text { suhu udara }\left({ }^{\circ} \mathrm{C}\right) \\
\mathrm{RH} & =\text { kelembaban udara relative }(\%)
\end{array}
$$

Data suhu dan kelembaban udara rata-rata harian periode 1980-2018 digunakan untuk menghitung nilai indeks Humidex. Selanjutnya akan dianalisa tren nilai Humidex rata-rata bulanan periode 1980-2018 untuk melihat fluktuatif data

\begin{tabular}{|c|c|}
\hline $\begin{array}{l}\text { Indeks } \\
\text { Humidex }\end{array}$ & Kategori Interpretasi \\
\hline$\leq 29^{\circ} \mathrm{C}$ & Nyaman \\
\hline $30-34^{\circ} \mathrm{C}$ & Perasaan sedikit tidak nyaman \\
\hline $35-39{ }^{\circ} \mathrm{C}$ & Perasaaan tidak nyaman \\
\hline $40-45^{\circ} \mathrm{C}$ & $\begin{array}{l}\text { Perasaan sangat tidak nyaman akibat } \\
\text { panas hingga menimbulkan rasa tersengat } \\
\text { akibat panas }\end{array}$ \\
\hline $46-53^{\circ} \mathrm{C}$ & $\begin{array}{l}\text { Perasaan sangat tidak nyaman dan } \\
\text { hampir dapat menyebabkan penyakit } \\
\text { akibat serangan panas }\end{array}$ \\
\hline$\geq 54^{\circ} \mathrm{C}$ & Kematian akibat panas \\
\hline
\end{tabular}
apakah cenderung naik atau turun. Interpretasi nilai indeks Humidex sesuai dengan Tabel 1 (Spridonov, dkk., 2013).

Tabel 1. Interepretasi indeks panas Humidex

Dalam penelitian ini, analisis perbandingan nilai indeks Humidex terhadap kecepatan angin dan jumlah kendaraan bermotor di Kota Tanjungpinang dilakukan untuk mengetahui pengaruhnya terhadap tingkat kenyamanan thermis di Kota Tanjungpinang. Perbandingan dilakukan dengan menggunakan metode regresi linear sederhana. Persamaan umum metode regresi linear sederhana, yaitu :

$$
y=a x+b
$$

Keterangan :

$y=$ variabel terikat

$\mathrm{x} \quad=$ variabel bebas

$\mathrm{a}$ dan $\mathrm{b}=$ konstanta kemiringan (slope) dan intercept

Selanjutnya akan dilakukan evaluasi terhadap persamaan regresi menggunakan Korelasi Pearson (r). Korelasi Pearson (r) digunakan untuk mengetahui nilai penyimpangan antara variabel bebas (x) dengan variabel terikat (y). Dari nilai $r$, dapat dilakukan analisa apakah memiliki nilai penyimpangan besar atau kecil. Persamaan umum Korelasi Pearson (r), yaitu :

$$
r(x, y)=\frac{n \cdot \sum X Y-\sum x \cdot \sum Y}{\sqrt{\left[n \cdot \sum x^{2}-\left(\sum x\right)^{2}\right] \cdot\left\{\left(n \cdot \sum Y^{2}-\left(\sum Y\right)^{2}\right]\right.}}
$$

Menurut Sugiyono (2011) interpretasi korelasi (r) dibagi menjadi 5 kriteria pada Tabel 2.

Tabel 2. Kriteria koefisien korelasi

\begin{tabular}{cc}
\hline \hline Kriteria & Interpretasi Data \\
\hline Sangat Rendah & $0,0-0,199$ \\
Rendah & $0,2-0,399$ \\
Sedang & $0,4-0,599$ \\
Kuat & $0,6-0,799$ \\
Sangat Kuat & $0,8-1,0$ \\
\hline
\end{tabular}

\section{Hasil dan Pembahasan}

Suhu udara yang relatif tinggi (hangat) dalam banyak hal cukup menguntungkan manusia yang tinggal di wilayah tropis jika dilihat dari sudut pandang energi. Urban Heat Island (UHI) merupakan perubahan dan perbedaan suhu yang terjadi di lapisan udara di pusat kota dengan daerah di sekitarnya. Menurut Voogt (2002) dalam Iswanto (2008) menyatakan UHI yaitu suhu udara yang lebih panas di daerah urban (perkotaan) dibandingkan dengan daerah non urban. Gambar 1 menginterpretasikan pola suhu dan kelembaban udara di Kota Tanjungpinang untuk periode 19892018. Berdasarkan Gambar 1, pola suhu udara berkebalikan dengan pola kelembaban udara. Wilayah Tanjungpinang dikategorikan sebagai wilayah Non-ZOM (Zona Musim) dimana secara klimatologis memiliki dua pola puncak hujan tertinggi yang tercatat terjadi di bulan Mei dan November. Peningkatan suhu udara (lebih hangat) berdampak terhadap penurunan kelembaban udara (massa udara kurang lembab) atau sebaliknya. Suhu udara rata-rata bulanan berkisar $25-27{ }^{\circ} \mathrm{C}$ dan kelembaban udara rata-rata bulanan berkisar 80-90 $\%$ untuk wilayah Kota Tanjungpinang. Suhu udara cukup panas di bulan Mei-Agustus. Hal tersebut sebagai dampak dari kurang giatnya konvektifitas antara atmosfer dan lautan sehingga curah hujan yang terjadi biasanya sedikit. Suhu udara cukup dingin di bulan November-Januari. Hal tersebut sebagai dampak dari intensitas curah hujan yang cukup tinggi sehingga menyebabkan suhu udara cukup dingin dan kelembaban udara cukup basah.

Pola (trend) nilai Humidex di Kota Tanjungpinang untuk periode 1989-2018 disajikan dalam Gambar 2. Hasil menunjukkan rata-rata nilai Humidex bulanan berkisar antara 32.6-34 ${ }^{\circ} \mathrm{C}$. Nilai terendah Humidex terjadi pada tahun 1996 berkisar 31-32 ${ }^{\circ} \mathrm{C}$ dan nilai tertinggi terjadi pada tahun 2016 berisar $34-35.5^{\circ} \mathrm{C}$. Nilai tertinggi Humidex rata-rata bulanan terjadi pada bulan Mei dan Juni, sedangkan nilai terendah terjadi pada bulan Januari. Terjadi kecenderungan peningkatan Humidex berkisar 0.08$0.9{ }^{\circ} \mathrm{C}$ dan penurunan Humidex berkisar 0.07-0.8 ${ }^{\circ} \mathrm{C}$. Nilai indeks panas Humidex menunjukkan besaran yang lebih tinggi dibandingkan suhu udara yang diamati secara observasi. Hasil penelitian yang dilakukan Ratna, dkk. (2013) dan Wati dan Nasution (2018) juga menunjukkan nilai yang dirasakan oleh seseorang akibat suhu dan kelembaban udara yang menyebabkan panas yang diterima oleh seseorang 
lebih tinggi dibandingkan dengan nilai suhu udara yang teramati. Berdasarkan Gambar 2, nilai Humidex mengalami peningkatan dengan nilai koefisien determinasi sebesar 0.55. Hal tersebut sebagai dampak dari adanya peningkatan suhu maksimum harian yang lebih kuat dibandingkan dengan peningkatan suhu udara rata-rata dan minimum nya.

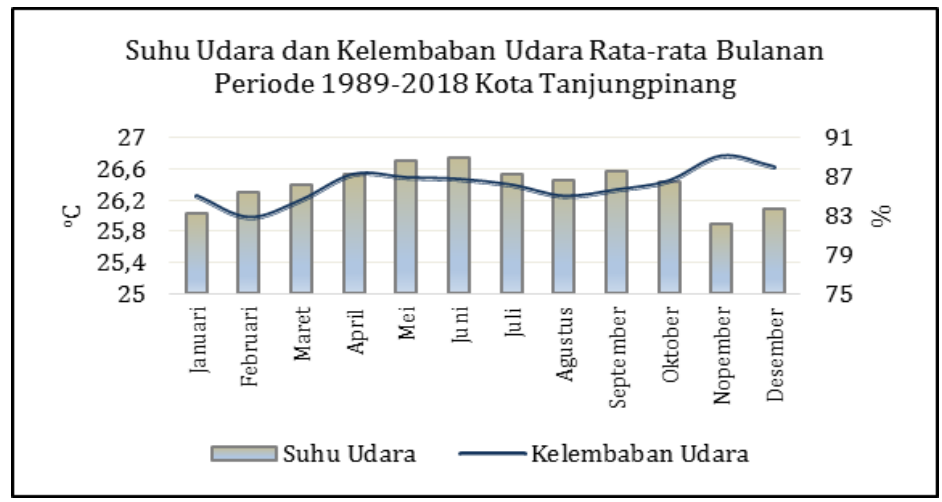

Gambar 1 Pola suhu dan kelembaban udara Kota Tanjungpinang (Pengolahan data, 2019)

Wati dan Nasution (2018) menyatakan dampak dari fenomena UHI yang paling dirasakan salah satunya adalah tingkat kenyamanan dan gangguan kesehatan akibat panas. Terjadinya kecenderungan peningkatan nilai Humidex salah satunya juga disebabkan oleh semakin tingginya laju perkembangan urbanisasi di wilayah perkotaan Kota Tanjungpinang. Hal tersebut dapat dilihat dari semakin maraknya pembangunan gedung atau perumahan di wilayah perkotaan (semakin berkembangnya lahan terbangun). Perkembangan urbanisasi di Kota Tanjungpinang telah mempersempit konversi lahan hijau sehingga pemanasan suhu udara semakin meningkat dari tahun ke tahun. Pada dasarnya, perubahan penutupan lahan akan mengubah sifat-sifat fisis permukaan seperti albedo dan emisivitas yang berdampak terhadap perubahan panas yang diterima oleh permukaan bumi. Implikasinya adalah apabila suatu penutup lahan terkonversi dari lahan bervegetasi menjadi daerah non vegetasi seperti bangunan pemukiman akan menyebabkan semakin luasnya daerah panas (kering). Apabila kondisi ini berlanjut akan menyebabkan tingkat kenyamanan termis akan berkurang menjadi tidak nyaman (Kalfuadi, 2009).

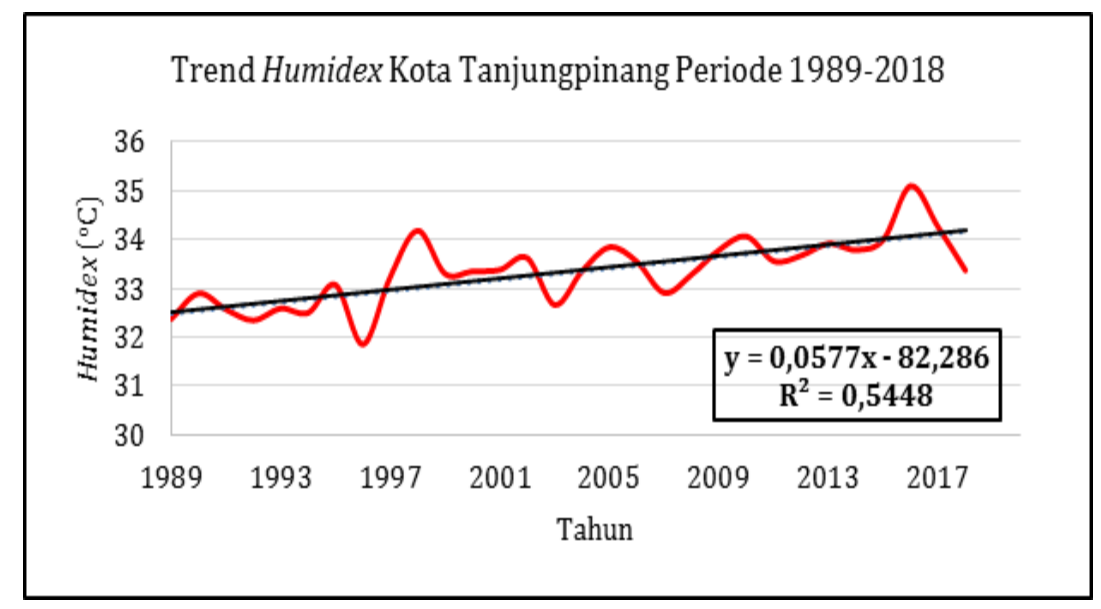

Gambar 2 Trend nilai Humidex di Kota Tanjungpinang (Pengolahan data, 2019)

Indeks panas Humidex merupakan besaran yang dapat dikaitkan dengan tingkat kenyamanan termis yang dirasakan oleh manusia dengan mengkombinasikan data suhu dan kelembaban udara relatif. Tabel 3 menginterpretasikan frekuensi kejadian sensasi panas yang teramati untuk wilayah Kota Tanjungpinang. Berdasarkan nilai Humidex yang dikategorikan menurut interpretasi yang dilakukan Spridinov, dkk. (2013), frekuensi tertinggi untuk kategori "perasaan sedikit tidak nyaman" yaitu 66.24 $\%$. Hal tersebut menunjukkan selama periode 1989-
2018, terjadi kecenderungan peningkatan indeks Humidex dengan signifkan (nilai lebih dari 50\%) sehingga menunjukkan tingkat kenyamanan di Kota Tanjungpinang cenderung semakin tidak nyaman. Frekuensi untuk kategori "nyaman" berkisar $1.19 \%$. Frekuensi untuk kategori "perasaan tidak nyaman" berkisar $32.49 \%$. Frekuensi untuk kategori "perasaan sangat tidak nyaman akibat panas hingga menimbulkan rasa tersengat akibat panas" berkisar $0.08 \%$. Penelitian yang dilakukan Spridinov, dkk. (2013) dilakukan untuk wilayah beriklim sub-tropis. 
Pada dasarnya, interpretasi tersebut tentunya berbeda jika digunakan untuk wilayah beriklim tropis seperti Kota Tanjungpinang, sehingga sangat perlu dilakukan kajian lanjut untuk menghitung nilai sensasi panas yang dirasakan manusia yang tinggal di lingkungan tropis. Jika dilihat dari Tabel 3, populasi manusia yang tinggal di Kota Tanjungpinang dominan merasakan perasaan netral (nyaman hingga perasaan sedikit tidak nyaman) terhadap suhu udara yang seiring waktu mengalami peningkatan. Peningkatan nilai Humidex tetap dapat diatasi dengan menyesuaikan kondisi kenaikan suhu udara dimana secara alamiah manusia akan melakukan proses adaptasi terhadap suhu udara luar yang cukup tinggi. Pada dasarnya, semakin ke pusat kota, tingkat kenyamanan yang dirasakan manusia akan semakin tidak nyaman.

Tabel 3. Frekuensi kejadian sensasi panas yang dirasakan populasi yang tinggal di Kota Tanjungpinang berdasarkan interpretasi nilai menurut Spridinov, dkk. (2013)

\begin{tabular}{|c|c|c|}
\hline Kategori & Humidex & Persentase (\%) \\
\hline Nyaman & $\leq 29^{\circ} \mathrm{C}$ & 1.19 \\
\hline Perasaan sedikit tidak nyaman & $30-34{ }^{\circ} \mathrm{C}$ & 66.24 \\
\hline Perasaan tidak nyaman & $35-39^{\circ} \mathrm{C}$ & 32.49 \\
\hline $\begin{array}{l}\text { Perasaan sangat tidak nyaman } \\
\text { akibat panas hingga menimbulkan } \\
\text { rasa tersengat akibat panas }\end{array}$ & $40-45^{\circ} \mathrm{C}$ & 0.08 \\
\hline $\begin{array}{l}\text { Perasaan sangat tidak nyaman dan } \\
\text { hampir dapat menyebabkan } \\
\text { penyakit akibat serangan panas }\end{array}$ & $46-53^{\circ} \mathrm{C}$ & 0 \\
\hline Kematian akibat panas & $\geq 54^{\circ} \mathrm{C}$ & 0 \\
\hline
\end{tabular}

Kecepatan angin di daerah iklim tropis umumnya sedang. Angin dibutuhkan untuk keperluan ventilasi (untuk kenyaman penghuni yang ada di dalam bagunan). Terdapat kecenderungan peningkatan kenyaman termis melalui hembusan angin yang dirasakan langsung oleh manusia ketika menyentuh kulit tubuh. Melalui hembusan angin yang terjadi akan terjadi evaporasi keringat dari tubuh manusia yang berdampak langsung terhadap peningkatan rasa nyaman termis. Gambar 3 menginterpretasikan bagaimana kecepatan angin dapat mempengaruhi nilai Humidex di Kota Tanjungpinang untuk periode 1989-2018. Perbandingan pola kedua parameter secara klimatologis menunjukkan peningkatan kecepatan angin berdampak terhadap penurunan nilai Humidex, atau sebaliknya. Hal tersebut dapat dilihat pada bulan Maret-Juni dimana ketika terjadi pelemahan kecepatan angin (secara klimatologis pada bulan-bulan tersebut angin yang terjadi di wilayah Tanjungpinang yaitu variabel atau berubahubah) sehingga berdampak terhadap peningkatan nilai Humidex. Hubungan yang terbentuk antara kecepatan angin dan Humidex memiliki nilai koefisien determinan sebesar 0.41 dimana dikategorikan dalam kategori sedang. Sangkertadi (2006) menyatakan pengaruh kecepatan angin untuk meningkatkan rasa nyaman dapat diketahui jelas dengan analisis statistik menggunakan indeks DISC dimana hasil penelitiannya menunjukkan terdapat peningkatan kenyamanan termis melalui hembusan angin yang langsung menyentuh kulit tubuh manusia yang tinggal di daerah beriklim tropis lembab.

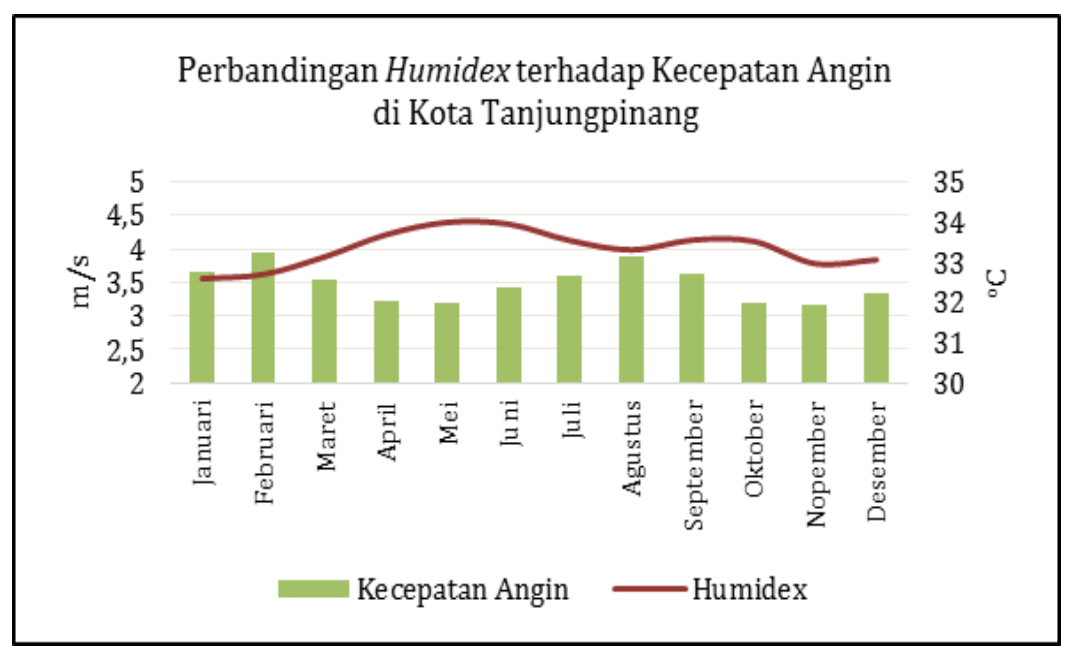

Gambar 3 Hubungan Humidex dengan kecepatan angin di Kota Tanjungpinang (Pengolahan data, 2019)

Hubungan antara UHI dengan tingkat kenyaman termis yaitu jika terjadi peningkatan nilai UHI maka terjadi peningkatan nilai indeks Humidex sehingga kondisi yang dirasakan populasi manusia yaitu kurang nyaman (menurunnya tingkat kenyaman termis) atau sebaliknya. Urbanisasi yang berdampak terhadap berkurangnya lahan hijau di Kota Tanjungpinang, juga berdampak terhadap semakin maraknya penggunaan kendaraan bermotor sebagai alat transportasi yang digunakan. Peningkatan tersebut berdampak terhadap peningkatan Gas Rumah Kaca (GRK) akibat semakin maraknya jumlah karbon yang merupakan hasil buangan dari kendaraan bermotor. Hal tersebut juga berdampak terhadap semakin panasnya suhu udara yang dirasakan oleh populasi manusia yang tinggal di Kota Tanjungpinang. Secara tidak langsung, peningkatan jumlah kendaraan di perkotaan akan mempengaruhi 
semakin giatnya UHI melalui emisi GRK seperti $\mathrm{CO}_{2}$, $\mathrm{NO}_{\mathrm{x}}, \mathrm{SO}_{2}$, dan lainnya. Pada dasarnya kendaraan bermotor merupakan penghasil emisi GRK terbesar yang berdampak terhadap akumulasi panas dari fenomena UHI (Kurdi, 2008). Volume gas $\mathrm{CO}_{2} \mathrm{di}$ dalam GRK menempati urutan kedua setelah uap air.

Gambar 4 menunjukkan bagaimana perubahan nilai Humidex akibat adanya peningkatan penggunaan jumlah kendaraan bermotor di Kota Tanjungpinang untuk periode 2014-2017. Keterbatasan penulis dalam memperoleh data jumlah kendaraan bermotor untuk series panjang, sehingga kurang terinterpretasikan dengan baik perubahan nilai indeks Humidex. Berdasarkan Gambar 4, jumlah kendaraan bermotor mengalami peningkatan secara eksponensial dengan koefisien determinan sebesar 0.34 dimana hubungan yang terbentuk diinterpretasikan dalam kategori rendah. Penelitian yang dilakukan Wati dan Nasution (2018) juga menunjukkan korelasi antara Humidex dengan jumlah kendaraan bermotor di DKI Jakarta mengalami peningkatan dengan koefisien determinan sebesar 0.54 namun hubungsn yang terbentuk diinterpretasikan dalam kategori sedang. Ketika terjadi peningkatan jumlah kendaraan bermotor dari waktu ke waktu, maka akan terjadi peningkatan nilai indeks Humidex juga. Hal tersebut terjadi sebagai dampak dari emisi GRK yang merupakan output (hasil keluaran) dari kendaraan bermotor. Peningkatan emisi GRK berdampak terhadap tingkat kenyaman termis yang dirasakan populasi yang tinggal di Kota Tanjungpinang menjadi kurang nyaman akibat polusi udara yang dihasilkan oleh kendaraan bermotor.

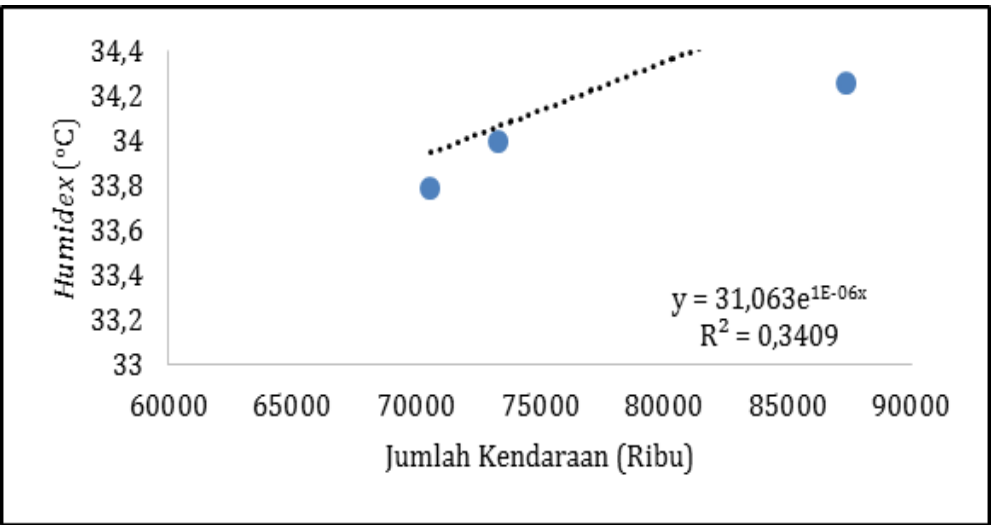

Gambar 4 Hubungan antara Humidex dengan jumlah kendaraan bermotor di Kota Tanjungpinang (Pengolahan data, 2019)

\section{Kesimpulan}

Berdasarkan data iklim periode 1989-2018 di Kota Tanjungpinang, hasil penelitian menunjukkan frekuensi tingkat kenyaman termis yang dirasakan populasi manusia yang tinggal berada pada kategori sedikit tidak nyaman (berkisar 66.24 \%). Hal tersebut terjadi sebagai dampak dari peningkatan nilai indeks panas. Tren peningkatan nilai indeks panas disebabkan akibat semakin meningkatnya perubahan penggunaan lahan menjadi lahan terbangun (non vegetasi), galaknya program urbanisasi, dan maraknya penggunaan kendaraan bermotor. Peningkatan kecepatan angin akan menyebabkan penurunan nilai Humidex atau sebaliknya. Terdapat peningkatan rasa nyaman termis ketika terjadi penurunan nilai Humidex atau sebaliknya.

\section{DAFTAR PUSTAKA}

Andani, N. D., Sasmito, B., Hani'ah. 2018. Pengaruh Perubahan Tutupan Lahan Terhadap Fenomena Urban Heat Island dan Keterkaitannya dengan Tingkat Kenyamanan Termal (Temperature Huumidity Index) di Kota Semarang. Jurnal Geodesi UNDIP. Vol. 7 No. 3. Hal 53-65.

BPS. Kota Tanjungpinang. 2018. Transportation Statistics. SAMSAT of Tanjungpinang Municipality.
Iswanto, P. A. 2008. Urban Heat Island di Kota Pangkalpinang Tahun 2000 dan 2006. Skripsi. Departemen Geografi. Universitas Indonesia. Depok.

International Standard. 1994. Moderate Thermal Environments-Determination of the PMV and PPD Indices and Specification of the Conditions for Thermal Comfort. Geneva. ISO 7730:1994.

Kalfuadi, Y. 2009. Analisis Temperature Heat Index (THI) Dalam Hubungannya Dengan Ruang Terbuka Hijau. Skripsi. Departemen Meteorologi dan Geofisika IPB. Bogor.

Karyono, T. H. 2001. Wujud Kota Tropis di Indonesia: Suatu Pendekatan Iklim, Lingkungan dan Energi. Jurnal Dimensi Teknik Arsitektur. Vol. 29 No.2. Hal 141-146.

Koerniawan, M. D. 2017. The Climate Sensitive Design in Hot-Humid Urban Design. Journal of Architecture and Built Environment. Vol. 44 No. 2. pp 137-142.

Kurdi, S. Z. 2008. Pengaruh Emisi $\mathrm{CO}_{2}$ dari Sektor Perumahan Perkotaan Terhadap Kualitas Lingkungan Global. Jurnal Permukiman. Vol. 3 No. 2. Hal 137-150.

Kurnia, R., Effendy, S., Tursilowati, R. 2010. Identifikasi Kenyamanan Termal Bangunan (Studi Kasus: Ruang Kuliah Kampus IPB Baranangsiang dan Darmaga Bogor). J. Agromet. Vol. 24 No. 1. Hal 14-22. 
Kusumastuty, K. D., Poerbo, H. W., dan Koerniawan, M. D. 2017. Climate-sensitive Urban Design Through Envi-Met Simulation: Case Study in Kemayoran. Jakarta. IOP Conference: Earth and Enviromental Science. IOP Publishing. ICCC 2017.

Maru, R. dan Ahmad, S. 2015. The Relationship Between Temperature Patterns Urban Morfometri in the Jakarta City, Indonesia. Asian Journal of Atmospheric Environment. Vol. 9 No. 2. pp 128-136.

Rana, R. B., Kusy, R., Jurdak, J., Wall, and Hu, W. 2013. Feasibility Analysis of Using Humidex as an Indoor Thermal Comfort Predictor. Energy and Buildings. Vol. 64. pp 17-25.

Sangkertadi. 2006. Peran Kecepatan Angin Terhadap Peningkatan Kenyamanan Termis Manusia di Lingkungan Beriklim Tropis Lembab. Jurnal Manusia dan Lingkungan. Vol. 13 No. 2. Hal 7189.

Santi, Belinda, S., Rianty, H., Aspin. 2019. Identifikasi Iklim Mikro dan Kenyamanan Termal Ruang
Terbuka Hijau di Kendari. NALARs Jurnal Arsitektur. Vol. 18 No. 1. Hal 23-34.

Siregar, D. C., Ardah, V. P., Kusumah, B. W. 2019. Pengaruh Aktivitas El Nino Southern Oscillation dan Dipole Mode Terhadap Curah Hujan di Tanjungpinang. Buletin Meteo Ngurah Rai. Vol. 5 No. 1. Hal 16-24.

Sobirin dan Fatimah, R. N. 2015. Urban Heat Kota Surabaya. Geodukasi. Vol. IV No. 2. Hal 46-69.

Spridonov, V., Curic, M., and Zafirovski, O. 2013 Weather and Human Health. COBISS M. K.

Sugiyono. 2011. Metode Penelitian Kuantitatif, Kualitatif, dan R\&D. Penerbit Alfabeta. Bandung.

Talarosha, B. 2005. Menciptakan Kenyamanan Termal Dalam Bangunan. Jurnal Sistem Teknik Industri. Vol. 6 No. 3. Hal 148-158.

Wati, T. dan Nasution, R. I. 2018. Analisis Kenyamanan Thermis Klimatologis di Wilayah DKI Jakarta dengan Menggunakan Indeks Panas (Humidex). Widyariset. Vol. 4 No. 1, Hal 89-102. 